\title{
Sex Preference and Reproductive Behaviour Among Married Couples in Esan Land: A Breeding Ground for Over-Population
}

\author{
AIWORIABOAKUELU, CHRISTOPHER E. 'Ph.D' \\ DEPARTMENT OF SOCIOLOGY, \\ FACULTY OF SOCIAL SCIENCES, \\ AMBROSE ALLI UNIVERSITY, EKPOMA, \\ EDO STATE, NIGERIA.
}

\begin{abstract}
There was a strong preference for male children which had persistently remained as a standing order among married couples of child bearing age (15-49) in Esanland. Undertaking the study, a sample size of 560 respondents was selected by multistage sampling method. Data collection focused majorly on two broad types: the quantitative (social survey method) and qualitative (in depth interview method). The researcher was interested in finding out if there were relationships existing between: a particular sex preference and high reproductive behaviour among couples, value placed on children and high reproductive behaviour among couples, as well as weight of spouse decision and desired family size. Percentage was used to analyze the demographic attributes of the respondents, while Chi-Square $\left(\mathrm{X}^{2}\right)$ was used to test the hypotheses formulated. Findings revealed that $87.6 \%$ of respondents keen for a particular sex mainly for perpetuity of family's name. Associated with this, is the value placed on children by married couples which pressurised them to have more children than their desired number. This becomes a pointer to high level of fertility and large family size. The implication is that women are not only exposed to a prolonged period of childbearing, posing threat to both the health of the mother and child, but also serves as a breeding ground for over population. However, some recommendations were put forward to abate the situation for more predictable and desirable population size capable of sustainability.
\end{abstract}

Key Words: Sex Preference, Reproductive Behaviour, Family Size and Over-population.

DOI: $10.7176 / \mathrm{JCSD} / 50-06$

Publication date:July $31^{\text {st }} 2019$

\section{INTRODUCTION}

Every minute, 150 babies are born in the world. That means about 220,000 new human beings a day and 90 million babies a year who need to be fed, clothed, sheltered, educated and employed. By this rate of population growth, many analysts believe that over-population is threatening the basic fabric of world order. The World Bank estimated that the year 2025, the global population will be 8.3 billion, 7 billion of whom will be residents of the poorest and least-developed nations (Tischler, 1996). In a similar vein, the United Nations forecasts that by 2050 the world's population will hit 9.3 billion (Moore, Aiken and Chapman, 2002). Also, the current world population as of January 2019 is 7.7 billion and it is projected to increase by slightly more than one billion people over the next 13 years, reaching 8.6 billion in 2030, and to increase further to 9.8 billion inhabitants in 2050 (United Nations, Department of Economic and Social Affairs, Population Division, 2017).

The effect of sex preference on fertility is actually more complicated than might appear at first glance. In many countries throughout the world, there is a strong preference for male children (Ushie, Enang and Ushie, 2013). Logically, this may not make much sense since in most underdeveloped and developing countries, daughters seem functional and active for the domestic works they are involved in. They typically help their mothers with household chores. Based on this, one would think that this would increase their worth to the family and even prefer to male children. This does not necessarily hold. In spite of the significant campaign for the equality and desirability of both sexes of children, empirical evidence and reality indicate that the practice of child-sex preference is still rampant in Nigeria, especially in the rural areas (Eguavoen, Odiagbe and Obetoh, 2007).

This study therefore becomes necessary to unveil the underlying factors influencing the relative benefits of sons over daughters and ultimately gender preference, which subsequently endanger maternal health and the fundamental fabric of world order.

\section{Statement of the Problem}

The basic fabric of the world order is capable of sustainability if it is not threatened by population growth. From the review of literature, it behoves us to know that the major factor that makes fertility to be very high among couples of childbearing age is infant mortality. In primitive societies, maintaining population had always been difficult. Women had to bear many children to ensure that several would survive to have children of their own. Historians believe that, in primitive groups, about 50 percent of all children died before the age of 5 (Petersen, 1975). 
As humans ceased being nomadic hunters and gatherers and settled in a particular place to grow crops, life became more secure. There was a lot of food, and it was regularly available. With better diet, we became healthier, and our reproductive rates finally began to outstrip death rates. More babies lived to maturity and the population began to grow more rapidly (Stark, 2001). Increased food supplies and the conquest of many diseases caused mortality to fall and therefore make the population to grow. One would have expected that at this stage, population would become relatively stable because of the high mortality that has been overcome, but what is being experienced is a persistent high fertility growth rate which has remained unabated.

From the literature, although it was indicated that the actual fertility outcome often exceeds the expectation of couples, yet the cause of this has not been adequately explained. However, a lot of expression has been made concerning children sex preference in Nigerian and African societies, but it may seem unrealistic when it is said that much emphasis has not been put to address it in relation to the problem of population growth and maternal health. It is against this background that this study was undertaken with the focus to unveil the consequential effects of children sex preference to humanity. Therefore, the question that readily comes to mind is: what is the implication for desirous of a particular sex preference by couples to the overall reproductive behaviour of the couples and indeed population situation in the study area? This main question and other related ones were fully addressed by this paper.

\section{Objectives of the Study}

The specific objectives of this study were put forward as follows:

1. To find out the factors responsible for sex preference.

2. To find out if the desire for a particular sex preference can lead to high reproductive behaviour among married couples in the study area.

3. To examine the influence of value placed on children in relation to reproductive behaviour among married couple in Esanland.

4. To find out the weight of reproductive decision in the family between the spouses.

5. To make some recommendations that would surmount the adverse effects of sex preference.

\section{Hypotheses} formulated.

On the basis of the statement of problem and objectives of this study, the following hypotheses were

1. There is no relationship between a particular sex preference and high reproductive behaviour among married couples in Esanland.

2. There is no relationship between the value placed on children and high reproductive behaviour among couples in Esanland.

3. There is no relationship between the weight of spouse's decision and desired family size among married couples in Esanland.

\section{Literature Review}

Over-population has been cited as internal obstacle preventing countries from development. It is argued that the economic growth necessary for industrial development is difficult to achieve because any spare capital is unlikely to be reinvested in developing industry. Instead, it is likely to be spent feeding the population in order to avoid civil unrest and political instability. In addition, the infrastructure of such societies, especially their health and education systems (which are already basic) are stretched to the limit (Moore et al., 2002).

Ehrlich (1968) argues that the high birth rate of developing countries has led to a "population explosion" which has put much strain on their limited resources of food and energy. This, allegedly, is responsible for the problems in the developing world such as famine, malnutrition, poverty, war, desertification (because of over-use of land), deforestation (because more hand is required for housing) and increasing environmental pollution.

Ninety million babies are born each year and by this rate of population growth, many analysts believe that over-population is threatening the basic fabric of world order. The World Bank estimates that in the year 2025 , the global population will be 8.3 billion, 7 billion of whom will be residents of the poorest and leastdeveloped nations (Tischler, 1996).

According to Moore, et al., (2002), the United Nations forecasts that by 2050 the world's population will hit 9.3 billion. The population of less developed countries is expected to rise from 4.9 billion in 2001 to 8.2 billion in 2050. Nine out of every ten people in 2050 will live in developing country. In contrast, only three of the more developed countries, the United States, Russia and Japan, are expected to remain among the most populous by 2025. Similarly, according to United Nations, Department of Economic and Social Affairs, Population Division (2017), the current world population as of January 2019 is 7.7 billion and it is projected to 
increase by slightly more than one billion people over the next 13 years, reaching 8.6 billion in 2030, and to increase further to 9.8 billion in 2050 and 11.2 billion by 2100 .

According to Ushie et al., (2013), the actual fertility outcome oftentimes exceeds the expectation of couples. Although reliable and comprehensive data are still very scanty in most African countries, evidence abound to show that the preference for a particular sex among couples (especially male child) is prevalent and has been found to have contributed immensely to large family size being experienced in most developing countries. The value traditionally placed on a particular sex is higher for one sex than the other.

Isuigo-Aganihe's (1993) view, that among the Igbo, children confer on families a sense of continuity, and prestige within the society; their labour input is crucial to the household's productive process; they provide reliable insurance and security at old age and also provide companionship and psychic satisfaction to parents and the kinship. It has been observed among Africans, Asians, the Middle East, Indians, among other people, a strong preference for sons over daughters prevails (Arnold, 1996; Cleland, Verral and Vaessen, 1983; Mutharayappa, Choe, Arnold and Roy, 1997). A number of studies have shown that some cultural, social and economic factors influence the relative benefits of sons over daughters and ultimately gender preference (Espenshade, 1997; Vlasoff, 1990; Friedman, Hechter, and Kanazawa, 1994).

Some studies conducted by Bardhan (1988) and Miller (1981), among others, have revealed at least three major reasons underlying son preference among the Indians as follows:

i) Economic utility of sons, for sons are more likely than daughters to provide family business, earn wages and support their family during old age. A son brings a daughter in-law into the family which brings additional help in both the household and as an economic source from the dowry paid by her parents.

ii) Socio-cultural utility; especially in patrilineal and patriarchal family systems where, being a son is important becomes an added advantage to the status of the family.

iii) Similarly, the utility of having sons, also rises from the important religious functions that only sons can provide. Thus, apart from the Indians, in many African societies, certain, if not all religious rites are performed by males; this therefore calls for the need to have sons to handle the funeral rites of deceased parents (Ushie, et al., 2013). So, in societies where the parents of a daughter have to pay dowry to her husband, having many daughters is considered a liability to the parents (Kinshor, 1995).

However, according to Williamson (1983), the Philippines as a country, is one of the few countries where daughters are preferred over sons. In line with this, Dhanalingam (1994), finds that daughters are considered to provide more emotional satisfaction than sons to their parents.

But economic importance of male children in Ghana is evident from the fact that while less pressure is put on the daughters to make contributions towards the support of their parents; sons are morally obligated to take care of their parents in old age. Also compared to daughters, sons can put more hard work on fishing and farming for providing support of their parents and other relatives (Bhatia, 1984). In like manner, succession and inheritance are also channelled through the male line in patrilineal societies in Ghana (Nukunya, 2003). For property sharing, in some societies, the daughters are totally excluded, while in other societies, both sons and daughters share the property of their deceased parents, but the shares to the daughters are smaller. For instance, among the Anlo Ewe, personal property, landed or otherwise, passes from father to sons and daughters. As established rule, the sons take precedence over daughters, though the latter are not entirely excluded from the scheme of the share. Also, in polygamous families among the Krobo, property is shared on equal basis among the eldest sons of all women who are wives to the deceased who had male children for him. So, under Krobo law, women do not own or inherit land. The Tallensi system of inheritance is similar to Krobo in that women do not feature in the inheritance of landed property. As such, a man's personal property devolves only to his sons. For this purpose, males are more likely to be preferred than females in such societies (Nukunya, 2003).

According to Odiagbe (2011), in many Nigerian communities, children are highly valued, and that barren or childless women are treated with disdain, as such, no one wants to be childless even by the death of all the children. Thus, couples who are having a few children are often subjected to enormous pressures from their relatives to have more.

In some countries with a strong sex-preference, couples stop having children only when they are satisfied with the sex composition of their family, typically, after the birth of a son (Dalla-Zuanna, 2001). Udebhulu (2014), puts it that in Esan culture, men are the receivers of inheritance; female children have no standing or rank in the family. As Okojie (1994), puts it that a woman never inherits the sword; or you do not have a daughter and named her the family keeper, she would marry and leave not only the family, but the village, a wasted asset. It is assumed that once a woman marries, all her possessions go to her husband, thus, draining the family's wealth.

In a similar manner, Isuigo-Abanihe (1993), says that women, in particular, depend on their sons to solidify their marriage and position in their marital homes since no government laws protect them from illtreatment and predatory claims of their husband's relatives, especially in the events of a husband's death. Abara (2012), says that traditionally, most parents prefer boys to girls, thus, right from birth women are viewed and 
treated as inferior or second class citizens. It is a calamity for a woman to give birth to only girls. The consequence is that the husband must marry another wife so as to ensure that his lineage does not go into extinction. According to Olusanya cited in Aiworiaboakuelu, Obetoh and Oboh (2016), among the Ishan (Esan) of Edo State, children are not only desired, male ones are preferred.

So, sex of children could lead to high fertility rates in Nigeria as expressed above. For instance, couples whose children are all females would under pressure seek for male children in order to retain the family name by inheritance of father's property. On the other hand, women with only male children also strive to have female children who will assist them in household duties. However, Isiugo-Abanihe (2003), puts it that the preference for male child is stronger and wide spread in Nigeria. This seriousness of having a son is stressed in all parts of the country especially among the Ibos culture, which therefore, holds male very supreme.

Aiworiaboakuelu, et al (2016), establish that large family size prevailed among married couples of childbearing age in the study area because they centred on marriage more of procreation than of companionship. This was affirmed from the study that they hardly stop giving birth to children at a number less than four. So, $67 \%$ of the respondents were found in the category of large family size which is a confirmation that many children are greatly desired among the married couples in Esan Central Senatorial District of Edo State.

Fawcett (1996), says "the first birth signifies for parents such factors as adulthood, parenthood, virility or femininity and fulfilment of marriage". The first birth in turn, engenders other motivations for a second child, such as desire to provide a companion for the good of the first and balancing sex in the interest of each of the spouses often leads to high reproductive behaviour among the married couples in a particular environment.

As revealed from above, large family size is prevalence because of male preference which seems to even serve as the major contributing factor and also the ever ready of the married couples to procreate irrespective of the number of children on ground, as well as attempts to balance both sexes by couples.

\section{Theoretical Framework}

Functional analysis also referred to as functionalism or structural functionalism, is a theoretical framework in which society as a unit is composed of various interrelated parts that work together, each with a function that, when fulfilled, contributes to the stability of the entire system or society. In fact, it explores how social structures promote the stability and integration of society. Structural functionalism as viewed by Robert K. Merton (1910-2003), was used in this study to explain the attitude put up by married couples of child-bearing age in justifying their own action for sex preference. The functionalists such as Auguste Comte (1798-1857), Herbert Spencer (1820-1903), Emile Durkheim (1858-1917), Talcott Parsons (1902-1979), and others are of the view that to understand society, we need to look at both structures (how the parts of a society fit together the whole) and function (what each part does, how it contributes to the society) of such a social system.

In particular, Merton maintained the essence of functionalism as the image of society as a whole which composed of parts that work together. He used the term functions to refer to the beneficial consequences of people' action which help keep a group (society or social system) in equilibrium. In contrast, dysfunctions are consequences that harm a group (society or social system which determine a system's equilibrium.

So, Merton (1968), notes that some functions of any social pattern or structure are more obvious than others. Functions can be either manifest or latent. The manifest functions are the recognised (visible) and intended consequences (effects) of any social pattern or social structure, while latent functions are consequences that are largely unrecognised (invisible) and unintended. If any action is intended to help some parts of a system, it is a manifest function; while an action having latent function can have unintended (unrecognised) beneficial consequences that help a system adjust. Furthermore human actions can also hurt a system, this he referred to as latent dysfunctions. Therefore, whenever we examine a smaller part, we need to look for its functions and dysfunctions to see how it is related to the larger unit. In other words, Merton showed that social patterns have differing consequences for various members of a society. For example, conventional families may accomplish important tasks such as childbearing but they also limit the opportunities of women in the process.

In this study therefore, sex preference as the intended action, a manifest function put up by the married couples, helps part of a system by the function it displays in ensuring continuity or perpetuity of family's name, especially for those who bent on male preference and equal composition of sexes (i.e., balancing the sex in the interest of each of the spouses). In fact, a male child at least is needed by every couple, who would inherit the property. By this, the family name does not go into extinction. This equally stabilizes or solidifies the position of women in their marital homes and gives a source of satisfaction to the family.

Sex preference as latent function (unintended beneficial consequences) could lead to large family size, especially when the particular sex needed fails to surface or come at the desired time. The resulted large family size could then help to establish more families when the children are married respectively. The children from the off-shoot of large family size in the process of selection of sexes, could help parents for domestic chores and the raising of farm produce if the parents are farmers. Meanwhile, there will always be more hands in helping parents for labour, defence and financial support when they grow up. 
On the other hand, large families as latent dysfunctions, abound, limiting the opportunities of women and negating the viable social system, of course, a display of systemic trepidation. The society in this manner becomes endangered with poor levels of education, income, health and welfare, as well as high level of congestion, malnutrition, mortality, poverty and so on. In its grip of expansion, over-population comes on board, negatively affecting the political and socioeconomic positions of the society. This pushes afar sustainable development to a place where it becomes either intractable or impossible to redeem.

\section{Materials and Method}

The field work of this study was carried out in Esanland of Edo State, comprising five (5) Local Government Areas, namely: Esan West (with 10 political wards), Esan Central (with 10 political wards), Esan North-East (with 11 political wards), Esan South-East (with 10 political wards) and Igueben (with 10 political wards). The population of study were the married couples who were within the childbearing age. A sample size of five hundred and sixty (560) respondents was drawn from the entire population of interest.

Multi-stage sampling method was adopted in selecting respondents from twenty (20) political wards (i.e. 4 political wards from each Local Government Area), whose selection was by simple random sampling method from the fifty one (51) political wards in the entire area of the study. In each political ward, twenty eight (28) respondents were selected, out of which two (2) respondents (Chief or titled man and wife) were purposively selected from each political ward, making a total of eight (8) respondents in a Local Government Area and forty (40) respondents in the entire area of study (i.e. the five Local Government Areas). These respondents purposively selected which are believed to have special or detailed knowledge of the subject of the study, were subjected to in-depth interview (qualitative type of data collection). However, in the course of selecting the other twenty six (26) respondents from each political ward sampled, a sampling frame of building and households in each political ward was drawn up from where households were selected, using systematic sampling method. The pilot study recently carried out revealed that each political ward has up to one hundred and thirty (130) households. On the basis of this, thirteen (13) households were selected from each political ward (i.e. a household sampled from every 10 households). This gave a total of twenty six (26) respondents (13 males and 13 females-husband and wife in pairs as information source) from each political ward. Thus, the five (5) Local Government Areas from which twenty (20) political wards were selected, produced a total of five hundred and twenty (520) respondents subjected to survey method (quantitative type) of data collection.

Data collection therefore was mainly by survey method, complemented with in-depth interviews for more reliable and viable data. Data analysis was however based on Percentage and Chi-Square Statistical Test.

\section{ANALYSIS AND INTERPRETATION OF DATA Analysis and Interpretation of Data}

Out of the initial five hundred and twenty (520) surveys designed, 500 became the basis upon which data gathered were presented. The other twenty (20) not utilised were either half filled or missing. On the other hand, forty (40) respondents who were subjected to in-depth interview were analysed and interpreted separately, but used as complement to the analyzed data collected by quantitative method.

Particular Sex Preference: The distribution as shown in the table above, revealed that 220 (44\%) of the respondents were in need for a particular male sex, whereas $70(14 \%)$ of the respondents were keen on a particular female sex and 148 (29.6\%) of them bent on equal composition of sexes. However, $62(12.4 \%)$ of the respondents were for desirous for any sex (i.e. any sex is highly acceptable).

Reasons for a particular male sex as given by them were that the males are for continuity of family's name, inheritance of family's property and as means also of parents seeing themselves. On the other hand, some preferred female to male sex for early grand children and as avenue also for receipt of both financial and social support elsewhere, especially when they are given away for marriage. Those who opted for equal composition of sexes were for peace to rain at home and avoid domination. According to them, "when composition of sexes is balanced it portrays peaceful, happy and perfect family". So percentage put together for the respondents who were for a preferred sex was $87.6 \%$. Situations where couples prefer son or daughter to balance the desired sex of children invariably lead to large family size. This is because reproductive behaviour is largely a response to the underlying preference of parents for children. For instance, a situation where a particular sex desired or needed does not easily surface or come on board or in a situation where the attitude of balancing the sex in the interest of each of the spouses, will definitely pave the way to high reproductive behaviour among the married couples in a particular environment.

However, those who were not bent on a particular sex but desirous of any sex were of the opinion that both sexes (males and females) and imbalanced composition of sexes attract some importance, and that any sex at a particular time is always God's choice which of course is the best choice ever. 
Percentage Distribution of Respondents by Demographic Attributes (Particular Sex Preference, Family Size, Value Placed on Children and Family Decision Making)

\begin{tabular}{|l|r|c|}
\hline Variable & \multicolumn{1}{|c|}{ Number of Respondents } & Percentage (\%) \\
\hline Particular Sex Preference: & 220 & 44 \\
Male & 70 & 14 \\
Female & 148 & 29.6 \\
Equal composition of sex & 62 & 12.4 \\
Desirous of any sex & $\mathbf{5 0 0}$ & $\mathbf{1 0 0}$ \\
\hline Total & & $\mathbf{6 5 . 8}$ \\
\hline Family Size: & 329 & 34.2 \\
Large & 171 & $\mathbf{1 0 0}$ \\
Small & $\mathbf{5 0 0}$ & \\
\hline Total & & 48.2 \\
\hline Value Placed on Children: & 241 & 10.0 \\
Continuity of family's name & 50 & 37.2 \\
Feeling of competence as parents & 186 & 4.6 \\
Old age security for the parents & 23 & $\mathbf{1 0 0}$ \\
Avoidance of loneliness & $\mathbf{5 0 0}$ & 22 \\
\hline Total & & 6 \\
\hline Decision on the Number of Children: & 110 & $\mathbf{7 2}$ \\
\hline Husband's decision & 30 & $\mathbf{1 0 0}$ \\
\hline Wife's decision & 360 & $\mathbf{5 0 0}$ \\
\hline Joint decision & & \\
\hline Total & & \\
\hline Source & & \\
\hline
\end{tabular}

Source: Field Survey, 2018.

Family Size: The table on this aspect revealed the distribution of respondents on family size, showing that 329 $(65.8 \%)$ of respondents had large family size as against $171(34.2 \%)$ of respondents with small family size. The adduced reasons why majority of the respondents (couples) had large family size are traceable to the sociocultural contexts of the study area such as: (i) a situation arising from sex preference by certain couples especially when the needed sex at a particular time refuses to feature. (ii) a way of fighting against high infantchild mortality risk by urging parents (couples) to have more children than they otherwise would have as a hedge against infant-child loss. (iii) having more hands in helping parents for defence, labour, financial support when they grow up, and also as a "looking glass" through which parents see themselves or "photographs" through which others see them (parents) after their deaths, and particularly if the children have achieved success in life.

Value Placed on Children: The above table showed that $241(48.2 \%)$ of the respondents were in support of "continuity of family's name" (a means of seeing themselves) as benefit derivable from having children, 50 $(10 \%)$ of them were in support of "feeling of competence as parents", $186(37.2 \%)$ of them were in support of "old age security for parents", while $23(4.6 \%)$ of the respondents were in support of "avoidance of loneliness" as benefits derivable from having children.

On the whole, it was revealed that the respondents with continuity of family's name as value placed on having children had the highest frequency $241(48.2 \%)$, followed by those in old age security for the parents and feelings of competence as parents. This implies that in Esanland, the benefits derivable from having children are mainly centred on family cohesiveness and continuity as well as economic support and physical care for the old age parents, so according to them, the reason for many or more children is that children serve as assets and investments as well as prestigious outfits for the family. Thus, the positive value which the majority of the respondents derive from having children makes them to imbibe with the tendency to have more.

Decision on the Number of Children: The table on this showed the distribution of respondents according to the number of children a coupled should have. As can be seen from the table, 110 (22\%) of the respondents argued that husband should take the decision on the number of children for a couple since he is the head of the family and decision maker including reproductive decision, $30(6 \%)$ of them argued that women (wives) being the one who actually bear the burden of pregnancy, should decide whether to have additional children or not. However, $360(72 \%)$ of the respondents believed that it should be a joint decision since children upbringing and care solely rely on a collective responsibility of both spouses.

\section{Hypothesis Testing and Interpretation}

The hypotheses formulated in this study were: 
1. There is no relationship between a particular sex preference and high reproductive behaviour among married couples in Esanland.

2. There is no relationship between value placed on children and high reproductive behaviour among married couples in Esanland.

3. There is no relationship between the weight of spouse's decision and desired family size among married couples in Esanland.

\section{Hypothesis 1}

$\mathrm{H}_{0}$ : There is no relationship between a particular sex preference and high reproductive behaviour among married couples in Esanland.

$\mathrm{H}_{1}$ : There is no relationship between a particular sex and high reproductive behaviour among married couples in Esanland.

Relationship Between Particular Sex Preference and High Reproductive Behaviour Among Married Couples in Esanland

\begin{tabular}{|l|r|l|r|}
\hline \multirow{2}{*}{ Particular Sex Preference } & \multicolumn{2}{|c|}{ Couple's Reproductive Behaviour } & \multirow{2}{*}{ Row Total } \\
\cline { 2 - 4 } & \multicolumn{1}{|c|}{ High } & 220 \\
\hline Male & 180 & 40 & 70 \\
Female & 60 & 10 & 148 \\
Equal Composition of Sexes & 80 & 68 & 62 \\
Desirous of Any Sex & 35 & 27 & $\mathbf{5 0 0}$ \\
\hline Total Column & $\mathbf{3 5 5}$ & $\mathbf{1 4 5}$ & \multicolumn{2}{c}{} \\
\hline
\end{tabular}

Source: Field Survey, 2018.

Calculated Chi-Square value $\left(\mathbf{x}^{2} \mathbf{c}\right)=\sum^{(\mathbf{o i}-\mathbf{e} \mathbf{i})^{2}}=\mathbf{e i} .88$

Total of value of Chi-Square $\left(\mathrm{x}^{2} \mathrm{t}\right)=7.82$

Degree of Freedom (DF) $=3$

Alpha Level of Significance $=0.05$

Decision: Since the calculated Chi-Square value $\left(x^{2} t\right)$ of 46.88 was greater than the table value of Chi-Square value $\left(x^{2} t\right)$ of 7.82 , at alpha level of 0.05 and degree of freedom of 3 , the null-hypothesis $\left(\mathrm{H}_{0}\right)$ of no relationship is rejected. This means that a relationship was found to exist between a particular sex preference and high reproductive behaviour.

The interpretation of the analysis means that (couples) who are involved in selection of sex or in preference of a particular sex (i.e., specific desire for a son or daughter, or equal composition of sexes), always have high reproductive behaviour (large family size). This is because; reproductive behaviour is largely a response to the underlying preference of parents for children.

The above finding somewhat conforms with Okojie (1994) and Udebhulu (2014), that in Esan culture, men are the receivers of inheritance, female children have no standing or rank in the family and that a woman never inherits the sword; or 'you do not have a daughter and named her the family keeper, she would marry and leave not only the family, but the village, a wasted asset'. It is assumed that once a woman marries, all her possessions go to her husband, thus, draining the family's wealth.

\section{Hypothesis 2}

$\mathrm{H}_{0}$ : There is no relationship between value placed on children and high reproductive behaviour among married couples in Esanland.

$\mathrm{H}_{1}$ : There is relationship between value placed on children and high reproductive behaviour among married couples in Esanland. 
Relationship Between Valued Placed on Children and High Reproductive Behaviour Among Married Couples in Esanland

\begin{tabular}{|l|r|r|r|}
\hline \multirow{2}{*}{ Value Placed on Children } & \multicolumn{2}{|c|}{ Couple's Reproductive Behaviour } & Row Total \\
\cline { 2 - 4 } & \multicolumn{2}{|c|}{ High } & \multicolumn{2}{c|}{ Low } & \\
\hline Continuity of family's name & 189 & 52 & 241 \\
Competence as Parents & 40 & 10 & 50 \\
Future Security of Parents & 99 & 87 & 186 \\
Avoidance of Loneliness & 14 & 9 & 23 \\
\hline Total Column & $\mathbf{3 4 2}$ & $\mathbf{1 5 8}$ & $\mathbf{5 0 0}$ \\
\hline
\end{tabular}

Source: Field Survey, 2018.

\section{Calculated Chi-Square value $\left(x^{2} \mathbf{c}\right)=\sum^{(\mathbf{o i}-\mathbf{e})^{2}}=\mathbf{e i}$}

Total of value of Chi-Square $\left(\mathrm{x}^{2} \mathrm{t}\right)=7.82$

Degree of Freedom $(\mathrm{DF})=3$

Alpha Level of Significance $=0.05$

Decision: Since the calculated Chi-Square value $\left(x^{2} c\right)$ of 34.73 was greater than the table value of Chi-Square $\left(x^{2} t\right)$ of 7.82, at alpha level of 0.05 and a degree of freedom of 3 , the null-hypothesis $\left(\mathrm{H}_{0}\right)$ is rejected. This implies that a relationship exists between valued placed on children and high reproductive behaviour among married couples in Esanland.

The interpretation is that in Esanland, the value placed on children is mainly centred on continuity of family's name as well as economic support and physical care for the old age parents. Also, children serve as a bond between husband and wife, as well as fulfilment of marriage and completeness of family life.

The above finding is in conformity with Isuigo-Abanihe's (1993) view, that among the Igbo, children confer on families a sense of continuity, and prestige within the society, their labour input is crucial to the household's productive process' they provide reliable insurance and security at old age and also provide companionship and psychic satisfaction to parents and the kinship.

\section{Hypothesis 3}

$\mathrm{H}_{0}$ : There is no relationship between weight of spouse's decision and desired family size.

$\mathrm{H}_{1}$ : There is relationship between weight of spouse's decision and desired family size.

Relationship between Weight of Spouse's Decision and Desired Family Size

\begin{tabular}{|l|c|c|c|}
\hline Weight of Spouse's Decision on the & \multicolumn{2}{|c|}{ Couple's Reproductive Behaviour } & \multirow{2}{*}{ Row Total } \\
\cline { 2 - 3 } Number of Children & \multicolumn{1}{|c|}{ High } & \\
\hline Husband's Decision & 84 & 26 & 110 \\
Wife's Decision & 20 & 10 & 30 \\
Joint Decision & 225 & 135 & 360 \\
\hline Total Column & $\mathbf{3 2 9}$ & $\mathbf{1 7 1}$ & $\mathbf{5 0 0}$ \\
\hline
\end{tabular}

Source: Field Survey, 2018.

Calculated Chi-Square value $\left(\mathbf{x}^{2} \mathbf{c}\right)=\sum \frac{(\mathbf{o i}-\mathbf{e i})^{2}}{\text { ei }}=7.20$

Total of value of Chi-Square $\left(\mathrm{x}^{2} \mathrm{t}\right)=5.99$

Degree of Freedom (DF) $=2$

Alpha Level of Significance $=0.05$

Decision: Since the calculated Chi-Square value $\left(\mathrm{x}^{2} \mathrm{c}\right)$ of 7.20 was greater than the table value of Chi-Square $\left(x^{2} t\right)$ of 5.99, at alpha level of 0.05 and a degree of 2, the null-hypothesis of no relationship is rejected. This therefore implies that a relationship exists between weight of spouse's decision and desired family size. 
The interpretation is that in Esanland, the weight of spouse's decision on the number of children married couples should have rests on the joint decision of both spouses with the emphasis that children upbringing and care solely lean on collective efforts.

\section{DECISION OF FINDINGS}

This opens way for widespread decision of findings unveiled in this study. As revealed by Okojie (1994) and Udebhulu (2014), that in Esan culture, men are the receivers of inheritance, female children have no standing or rank in the family, that a woman never inherits the sword; or you do not have a daughter and name her the family keeper, she would marry and leave not only the family, but the village, a wasted asset. Equally in line with the above, is Isiugo-Abanihe's (1993) view, that women; in particular, depend on their son to solidify their marriage and position in their marital homes since no government laws protect them from ill-treatment and predatory claims of their husband's relatives especially in the event of husband's death. Abrara (2012), says that it is calamity for a woman to give birth to only girls. The consequence is that the husband must marry another wife as to ensure that his lineage does not go into extinction. Ushie et al., (2013), put it that evidence abound to show that the preference for a particular sex among couples (especially male child) is prevalent and has been found to have contributed immensely to large family size being experienced in most developing countries.

This study therefore established that a relationship was found to exist between a particular sex preference of children and high reproductive behaviour among couples. This implies that married couples who are involved in selection of sex or in preference of particular sex (i.e., specific desire for a son or daughter or equal composition of sexes) always have high fertility rate. This is because the reproductive behaviour is largely a response to the underlying preferences of parents for children.

When couples have all males, the man is happy because he has an heir who will not only inherit his property, but one who will ensure that the family name does not go into extinction. The woman on the other hand, needs a male child to stabilize her in the husband's house and take care of her if the man (husband) eventually dies. Male children give her more assurance in the home than female children. But if all the children are males the woman may not accept family planning because she needs at least a female child in the next pregnancy to assist her in household duties.

On the other hand, a man is never happy with all female children, he needs at least a male child to inherit his property and ensure that his name does not erase from the family. If this is not achieved, he will never accept any attempt to reduce number of children. For those who are in need of combination of sexes, desired equal representation to avoid being dominated and ensure a peaceful home. This is how a particular sex preference comes into play in fertility analysis. The after-math of this attitude is a situation where couples would have children more than their initial desired family size.

The above is complemented with in-depth interview findings expressed as follows:

The truth has to be said when it comes to sex preference. In Esanland as far as I know and by the grace of God a chief in my community Uwalor-Oke Ward 9 in Uromi, a family without male child or children has automatically lost its position as a family because such family is already out of board. So for this singular reason, male children are preferred, because they will not only produce the needed joy for the family but also ensure perpetuity and cohesiveness of the family. Hence married couples avail all means in ensuring that male child or children are among the children they have (A teacher and chief from Uwalor-Oke Ward 9 in Uromi, Esan North East).

For me, every child is appreciable. But when you are married to a husband who has more than one wife, the issue of male child comes into play and becomes more valued than the female child because it is the male child at this time who solidifies your marriage and position as a woman in the family as long as the marriage lasts and after death. I am the first wife of my husband and the pressure of the environment where we live is that a married woman without male child or children means no defined and recognised position in her marriage. Otherwise, any sex is desirable (A woman teacher from Ugbegun Ward 10, Esan Central Local Government Area).

As has been found by Isiugo-Abanihe (1993), that among the Igbo, children confer on families a sense of continuity and prestige within the society, their labour input is crucial to the household's productive process; they provide reliable insurance and security at old age and also provide companionship and psychic satisfaction to parents and the kinship. In the same vein, Odiagbe (2011), puts it that in many Nigerian communities, children are highly valued, and that barren or childless women are treated with disdain, as such, no one wants to be childless even by the death of all the children. Thus, couples who are having few children are often subjected to enormous pressures from their relatives to have more. 
This study therefore revealed that a relationship exists between value placed on children and high reproductive behaviour among married couples. This implies that in Esanland, the benefits derivable from having children which mainly centred on family cohesiveness and continuity as well as economic support and physical care for the old age parents, fulfilment of marriage and completeness of family life, make the couples to imbibe with the tendency and propensity to have more children during their reproductive life.

The above is complemented with in-depth interview finding expressed as follows:

Nobody can dispute the joy derivable from rearing children. That is why those who are unable to have children on their own go for children adoption. So, bearing children is God's fulfilled function of procreation and when this is in force, the value parents place on children largely depends on the pressure projected by the environment which is the couples' place of abode. If you do not want to be stigmatized, you will imbibe what the environment (the society) demands. So, in Esanland, children are often desired. Therefore, as a wife to a known chief in this community, my pride of place in my husband's house are the children I bear for him (A female teacher and a wife to a Chief in Okalo Ward 7, Igueben Local Government Area).

The findings on the needs to find out if there is relationship between the weight of spouse's decision and desired family size, revealed the existence of relationship between the variables, signifying that the weight of spouse's on the number of children for couples rests solely on the joint decision of both spouses in Esanland, with emphasis that children upbringing embraces collective responsibilities of both spouses. According to the respondents such joint or collective decision ensures continuous peace in the family.

\section{Conclusion and Recommendation}

It is obvious that most societies especially the area under study, placed more emphasis and preference on the sex of children particularly the male children. The main reason for the preferred sex is for perpetuity of family's name thereby preventing the family from going into extinction. Other adduced reasons for a particular sex preference are cohesiveness of the family, solidification of women's marriage and position in the family as a bond between husband and wife, religious utility or function exclusively reserved for the males only, early grand children, labour input, household's productive process, reliable assurance and security at old age, companionship and psychic satisfaction to parents, and so on. It should be noted that as these lofty reasons sound so melodiously and convincing, the consequences posed by them (such as maternal health implications, large family size, over population) should not be handled with levity. Instead, should be taken seriously and proactively in order to avoid putting the society in a deplorable political and socio-economic stage where it will become irredeemable.

\section{On the basis of the above, the following recommendations were put forward:}

It is highly glaring from the findings that large family size is an after-math of a particular sex preference. It is a fact that over-population brings along with it a negation on political and socio-economic positions of the country at large, of which, life expectancy of such particular country ceases to improve because high infant mortality and fertility remain unabated. The adverse effects always impede sustainable development to humanity. To avert this therefore, the researcher stresses that married couples should learn the habit of seeing marriage as a fulfilment more of companionship than of procreation. If this is adhered to, the issue of a preferred sex may no longer be rampant because attention of couples will primarily be focused on marriage for companionship. The costs that would have been geared towards managing large family size resulting in overpopulation in the long run, would be converted into sustainable development thereby improving the living standard of the citizenry.

Findings obtained on sex preference revealed that couples are bent on a particular sex preference for perpetuity of family name and inheritance of family property, parents' old age security, stability of the position of women in the family, and so on. These of course, have in many ways led to high reproductive behaviour among married couples in Esanland especially when the needed sex at a particular time fails to surface. In the course of averting these consequential effects, the researcher posits that couples should take the bull by the horns to embrace both sexes as same importance and accept in good faith any sex at a particular time that comes to them. They should be ready to take up the responsibility of educating their children irrespective of the sex of their children. So, when children are well educated, there is always a better future for them. Their exposure no longer centred on how to inherit their parent's property but more on how to add value to or build on what is already laid down by their parents. The issue of family's name perpetuity, often traceable to the male children, will no longer make any difference if parents happen to have only female children. This is because abridged name is now adopted especially by the females in their husband's respective homes to prevent their parents' family name from going into extinction. A case of this is the former Honourable Minister of Finance Dr. (Mrs.) Ngozi Okonjo-Iweala who never wanted her father's name to be forgotten.

On old age security of parents, educated females seem more active in caring for parents than the males, especially when they are married into well to do families. It is the conviction of the researcher that if couples 
learn to see both sexes as important and therefore, take up the responsibility in educating every child irrespective of sex, it will not only reduce high fertility level but also abate the problems associated with the search desire for a particular sex.

It is hoped that with the implementation of the above recommendations, the adverse effects traceable to preferred sex which abound in the study area, and indeed the society at large will be surmounted.

\section{REFERENCES}

Abara, C.J. (2012). Inequality and Discrimination in Nigeria, Tradition and Religion as Negative Factors Affecting Gender. Gender and Ethnic Inequalities, Discrimination and other Human Rights Abuse. FIHRM, Lagos Zonal Office.

Aiworiaboakuelu, C.E.; Obetoh, G.I. \& Oboh, I.O. (2016). "Large Family Size and its Consequential Effects on Sustainable Development in Esan Central Senatorial District of Edo State”, African Journal of Social Sciences (England, United Kingdom), Vol. 6 No. 1 Pp. 105 - 113

Arnold, F. (1996). Son Preferences in South Asia. Paper Presented at the International Union for the Scientific Study of Population (IUSSP) Seminar on Comparative Perspective.

Bardhan, P.K. (1988). Sex Disparity in Child Survival in Rural India. In: T.N. Scrimivasan and P.K. Bardhan, ed. Rural Poverty in South India, 24:472-482.

Bhatia, J.C. (1984). Sex Preference of Children in Rural Ghana (West Africa). Health and Population: Perspective and Issues, 7(1), 32-47.

Cleland, J.; Verral, J. and Vassen, M. (1983). Preference for Sex of Children and their Influences on Reproductive Behaviour. World Fertility Survey. No 27. Voorburg: International Statistical Institute.

Dalla Zuanna and Leone, T. (2001). A Gender Preference Measure: The Sex Ratio at Birth, Genus. Lvii (1):3357.

Dharmalingam, A. (1994). Old Age Security: Expectations and Experiences in a South India Village. Population Studies: Journal of Demography, 48:5-19.

Eguavoen, A.N.T.; Odiagbe, S.O. and Obetoh, G.I. (2007). The Status of Women, Sex Preference, DecisionMaking and Fertility Control in Ekpoma Community of Nigeria. Journal of Social Sciences. 15(1), 43-49.

Ehrlich, Paul (1968). The Population Bom. New York: Ballantyne.

Espenshade, T.J. (1997). The Value and Cost of Children. Population Bulletin. 32:3-47.

Fawcett, J.T. (1976). The Value and Cost of Children: Converging Theory and Research, Proceeding of a Conference Held in Canberra. 16-18.

Friedman, D; Hechter, M. and Kanazawa, S. (1994). A Theory of the Value of Children. Demography. 31:375 401.

Isiugo-Abanihe, U.C. (1993). Socio-Cultural Context of High Fertility Among the Igbo. Women and Demographic Change in Sub-Saharan African, Darkar, Senegal, 3-6 March, 1993.

Isiugo-Abanihe, U.C. (2003). Male Role and Responsibility in Fertility and Reproductive Health in Nigeria. Lagos: Ababa Press Ltd.

Kinshor, S. (1995). Gender Differentials in Child Mortality: A Review of the Evidence. In: Monica Das Guptak, Lincoh C. Chen and T.N. Krisahabn, ed. Women's Health in India: Risk and Vulnerability. Pp 19 - 54. Bombay: Oxford University Press.

Merton, R.K. (1968). Social Theory and Social Structure. New York: Free Press. 
Miller, B.D. (1981). The Endangered Sex: The Neglect of Female Children in Rural North India. Ithaca: Cornell University Press.

Moore, Stephen; Aiken Dave and Chapman Steve (2002). Sociology for A2. London: Harper Collins Publishers, Hammersmith.

Mutharayappa, R.; Choe, M.K.; Armold, F. and Roy T.K. (1997). Son Preference and its Effects on Fertility in India. Mumbai: International Institute for Population Sciences.

Nukunya, G.K. (2003). Tradition and Change in Ghana: An Introduction to Sociology. Ghana University Press, Accra.

Odiagbe, S. (2011). Fertility Control in Nigeria: A Critical Review of Current Population Policy Option. Ekpoma Journal of Social Sciences. Ekpoma (1).

Okojie, C.G. (1994). Ishan Native Law and Customs with Ethnographic Study of Esan People. Benin City: Ilupeju Press Ltd.

Petersen, William (1975). Population. New York: Macmillan.

Stark, Rodney (2001). Sociology, Internet. Edition, $8^{\text {th }}$ ed. U.S.A.: Eve Howard, Wadsworth.

Tischler, H.L. (1996). Introduction to Sociology, Fifth Ed, USA: Holt, Rinehart and Winston, Inc.

Udebhulu, K.O. (2014). A Prince Kelly Udebhulu Cultural Heritage Point: The Culture Speaks Louder Among Esan People. School of Social and Human Resources, Internal University, Honolulu Hawaii.

United Nations, Department of Economic and Social Affairs, Population Division (2017). World Population Prospects: The 2017 Revision. NewYork: United Nations.

Ushie, M.A.; Enang, E.E.; Ushie, C.A. (2013). Implication of Sex Preference for Population Growth and Maternal Health in Obudu and Obanliku, Cross River State, Nigeria, Academic Research International, Vol 4. No. 3 Cross River: Savap International.

Vlasoff, C. (1990). The Value of Sons in India Village. Population Studies. 44, 5-20.

Williamson, N.E. (1983). "Parental Sex Preferences and Sex Selection", in N.G. Bennett, ed., Sex Selection of Children. New York: Academic Press. 